\title{
Hubungan Reseptor Estrogen, Reseptor Progesteron dan Ekspresi Her-2/Neu Dengan Grading Histopatologi pada Pasien Kanker Payudara di RSUD dr. Moewardi Surakarta
}

\author{
Warjianto $^{1}$, Widyanti Soewoto ${ }^{1}$, Untung Alifianto ${ }^{1}$, Hari Wujoso ${ }^{2}$ \\ 1. Bagian/SMF Bedah Fakultas Kedokteran Universitas Sebelas Maret RSUD Dr. \\ Moewardi Surakarta \\ 2. Medical Forensik Fakultas Kedokteran Universitas Sebelas Maret Surakarta RSUD \\ Dr. Moewardi Surakarta
}

Korespondensi : berlimacom@gmail.com

\begin{abstract}
ABSTRAK
Pendahuluan: Kanker payudara merupakan keganasan pada wanita yang memiliki prosentasi dan angka mortalitas cukup tinggi baik di dunia maupun Indonesia. Pada kanker payudara memiliki reseptor untuk hormon estrogen, progesteron, dan protein Her-2 yang berperan dalam proses terjadinya sel kanker. Dimana keberadaan ER, PR dan Her-2/Neu serta Grading Histopatologi sangat mempengaruhi manajemen dan prognosis pada pasien dengan karsinoma payudara.

Tujuan: Mengetahui hubungan antara Reseptor Estrogen, Reseptor Progesteron dan ekspresi Her-2/neu dengan grading histopatologi pada penderita wanita dengan kanker payudara.

Bahan \& Metode: Pasien kanker payudara sejumlah 73 orang yang berobat di Poliklinik dan dirawat di bangsal serta pengambilan sample di sub Bagian Bedah Onkologi RSUD dr. Moewardi Surakarta antara April sd Desember 2018. Pemeriksaan Immunohistokimia dan Histopatologi di bagian Patologi Anatomi RSUD dr. Moewardi Surakarta. Penelitian prospektif analitik korelasi dengan cross sectional.

Kesimpulan: Tidak terdapat hubungan antara reseptor estrogen dengan grading histopatologi pada pasien kanker payudara di RSUD dr. Moewardi Surakarta Jawa Tengah $(\mathrm{p}=0,901)$.Tidak terdapat hubungan antara reseptor progesteron dengan grading histopatologi pada pasien kanker payudara di RSUD dr. Moewardi Surakarta Jawa Tengah ( $\mathrm{p}=0,512)$.Tidak terdapat hubungan antara ekspresi Her-2/neu dengan grading Histopatologi pada pasien kanker payudara di RSUD dr. Moewardi Surakarta Jawa Tengah $(\mathrm{p}=0,629)$.
\end{abstract}

Kata Kunci: Kanker payudara, ER, PR, Her-2/Neu, Grading Histopatologi

\begin{abstract}
Introduction: Breast cancer is a malignancy in women who have a high percentage and mortality rate both in the world and Indonesia. Breast cancer has receptors for the hormones estrogen, progesterone, and Her-2 protein which play a role in the process of cancer cells. Where the existence of ER, PR and Her-2 / Neu and Histopathology Grading greatly affect the management and prognosis in patients with breast carcinoma.
\end{abstract}


Objective: To determine the relationship between Estrogen Receptor, Progesterone Receptor and Her-2 / neu expression with histopathological grading in women with breast cancer.

Material \& Methods: There were 73 breast cancer patients who were treated at the Polyclinic and treated in the ward and taking samples in the sub-section of Surgical Oncology Hospital Dr. Moewardi Surakarta between April to December 2018. Immunohistochemistry and Histopathology Examination in the Anatomy Pathology section of RSUD dr. Moewardi Surakarta. Prospective analytic correlation research with cross sectional study.

Conclusion: There is no relationship between estrogen receptors with histopathological grade in breast cancer patients at dr. Moewardi Surakarta, Central Java $(p=0,901)$. There was no relationship between progesterone receptors and histopathological grade in breast cancer patients at dr. Moewardi Surakarta, Central Java $(\mathrm{p}=0.512)$. There was no relationship between Her-2 / neu expression and histopathological grading in breast cancer patients at dr. Moewardi Surakarta, Central Java $(\mathrm{p}=0.629)$.

Keywords: Breast cancer, ER, PR, Her-2 / Neu, Histopathology grading.

\section{PENDAHULUAN}

Salah satu kanker yang sering terjadi, bahkan memiliki angka kejadian yang tinggi pada wanita adalah kanker payudara diama kejadian kasus baru setiap tahun mencapai angka 1,7 juta dan merupakan $25 \%$ dari semua jenis kanker. Tingkat kejadian kanker payudara tertinggi di Eropa Barat mencapai 89,7 per 100.000 dan terendah di Afrika Timur mencapai 19,4 per 100.000 orang. Pada tahun 2012, 228.926 kematian terjadi akibat kanker payudara di Asia. Di Indonesia, kanker payudara merupakan jenis kanker paling tinggi, baik pasien rawat jalan maupun rawat inap yang mencapai 12.014 orang $(28,7 \%)$ berdasarkan data dari Sistem Informasi Rumah Sakit pada 2010. Bahkan pada tahun 2013, kanker payudara di Indonesia mencapai 0,5 per 1000 perempuan dan merupakan prevalensi tertinggi kedua di Indonesia sebesar $0.5 \%$ dari Riset Kesehatan Dasar. Dimana angka kejadian kanker payudara tertinggi sebesar $2.4 \%$ terdapat di Provinsi D.I. Yogyakarta dibanding 34 provinsi lain di Indonesia ${ }^{1}$.

Data kanker payudara yang dilakukan pemeriksaan di Bagian Patologi Anatomi
RSUD Dr Moewardi dari tahun 2015 sampai dengan tahun 2017, baik yang berkunjung ke poliklinik sub bedah onkologi maupun yang menjalani rawat inap cukup banyak. Pada tahun 2015 pasien kanker payudara adalah sebanyak 434 pasien, tahun 2016 sebanyak 343 pasien, sedangkan pada tahun 2017 sebanyak 312 pasien.

Banyak faktor resiko sebagai penyebab kanker payudara, termasuk: usia, BRCA1 dan BRCA2 mutasi gen, riwayat keluarga, paparan sinar radiasi di dada, reproduksi, estrogen endogen, hormonal terapi, obesitas dan konsumsi alcohol. ${ }^{2}$

Pada kanker payudara memiliki reseptor untuk hormon estrogen, progesteron, dan protein Her-2, yang memungkinkan hormon atau protein yang berperan dalam proses terjadinya sel kanker. Analisis Reseptor Estrogen (ER), Reseptor Progesteron (PR) dan Her-2 / neu telah diterima sebagai prosedur tetap dalam manajemen pasien dengan kanker payudara. Gabungan ekspresi tiga reseptor hormon ini menjadi yang paling informatif dalam klasifikasi molekul tumor payudara dan penilaian klinis untuk pengobatan dan hasil lebih lanjut. ${ }^{3}$ 
Manajemen dan prognosis kanker payudara dipengaruhi oleh beberapa variabel, seperti: grade, staging, status reseptor hormon estrogen (ER), progesteron (PR) \& over ekspresi Her-2 / neu. Pada beberapa studi telah menemukan bahwa ekspresi ER, PR sebagai sebagai faktor yang berpengaruh terhadap grading histopatologi tumor dengan grade I (diferensiasi baik) tertinggi dan grade III (diferensiasi buruk) memiliki ekspresi ER / PR terendah. AdanyaHer-2 / neu yang over ekspresi dikaitkan dengan grade histologis burukdan juga karsinoma payudara dengan triple negative. Bhurgri et al menyatakan bahwa didapatkan hubungan yang signifikan antara profil hormonal reseptor estrogen, reseptor progesteron dan ekspresi her-2/neu dengan grading histopatologi pada penderita wanita dengan kanker payudara ${ }^{4}$.

Dari hasil penelitian mendapatkan hasil yang berbeda, yaitu tidak terdapat hubungan yang signifikan antara profil hormonal reseptor estrogen, reseptor progesterone dengan grading histopatologi ${ }^{5,6}$. Penelitian lain yang menyatakan bahwa tingginya kadar estradiol dalam plasma darah tidak berhubungan dengan tingginya grading histopatologi kanker payudara, tetapi yang berpengaruh terhadap grading histopatologi kanker payudara adalah lamanya paparan terhadap estradiol. Hasil dari sebuah penelitian bahwa antara Ekspresi Her-2/neu dengan grading histopatologi kanker payudara tidak terdapat hubungan yang signifikan ${ }^{6,7}$.

Dari beberapa perbedaan hasil penelitian di atas penulis tertarik untuk merancang penelitian terkait adakah hubungan antara Reseptor Estrogen, Reseptor Progesteron dan Ekspresi Her-2/neu dengan grading Histopatologi pada pasien kanker payudara di RSUD dr. Moewardi Surakarta Jawa Tengah? Sehingga diharapkan bisa menambah referensi terkait reseptor estrogen, reseptor progresteron dan ekpresi Her-2/Neu dengan grading histopatologi pada pasien kanker payudara dan menjadi bahan pertimbangan dalam menentukan manajemen terapi dan mengetahui prognosis pasien dengan kanker payudara.

\section{METODE}

Desain penelitian ini adalah observasional analitik dengan metode cross sectional dengan lokasi dan waktu penelitian dilaksanakan di Sub Bagian Bedah Onkologi RSUD dr. Moewardi Surakarta selama 9 bulan, terhitung mulai bulan April 2018 dengan Populasi Sasaran Semua pasien kanker payudara yang berobat di Poli dan dirawat dibangsal sub Bagian Bedah Onkologi RSUD dr. Moewardi Surakarta. Sampel dalam penelitian ini adalah pasien dengan kanker payudara baik perempuan pra dan pasca menopause yang berobat di Poli dan dirawat dibangsal sub Bagian Bedah Onkologi RSUD dr. Moewardi Surakarta dengan teknik Accidental Sampling dengan kriteria Eksklusi adalah kanker payudara residif atau rekuren.

Sumber data primer adalah data-data tentang hasil pemeriksaan reseptor hormon, Her2/Neu dan grading histopatologi daribiopsi jaringanpayudara yang periksa di Bagian patologi Anatomi RSUD dr. Moewardi Surakarta. Sumber data primer dikumpulkan dengan cara mengukur pemeriksaan reseptor hormon, Her-2/Neudan grading histopatologi dari biopsi jaringanpayudara secara langsung dengan responden. Sebelum dilakukan pengukuran kepada responden, peneliti menjelaskan kepada responden tentang maksud dan tujuan dari penelitian ini dan data responden akan dijaga kerahasiaannya, kemudian dimintai kesediaannya untuk menjadi sampel. Penelitian dan pengumpulan data pada saat peneliti melakukan penelitian saat itu juga.

\section{HASIL}

Jumlah subjek penelitian ini adalah 73 pasien kanker payudara yang berobat di Poli 
Warjianto et al. Hubungan Reseptor Estrogen, Reseptor Progesteron dan Ekspresi Her-2/Neu dengan Grading Histopatologi pada Pasien Kanker Payudara di RSUD dr. Moewardi Surakarta

dan dirawat dibangsal serta pasien yang menjalani operasi atau pengambilan sample PA di sub Bagian Bedah Onkologi RSUD dr. Moewardi Surakarta. Pemeriksaan reseptor hormonal, Her-2/Neu dan grading histopatologidari hasil biopsi dan operasi jaringan payudara dengan metode Immunohistokimia (IHK) dengan alat mikroskop cahaya. Pemeriksaan dilakukan di Laboratorium Patalogi Anatomi RSUD dr. Moewardi Surakarta. Gambaran data penelitian ini disajikan dalam model distribusi frekuensi dan prosentase, yaitu berupa: usia, Reseptor Estrogen (ER), Reseptor Prgresteron (PR), Human epidermal growth faktor receptor-2 (HER-2/neu), dan Grading Histopatologi diketahui bahwa usia pasien sebagian besar antara 46-55 tahun dan sebagian kecil < 36 tahun. Reseptor Estrogen (ER) positif ada 26 pasien (35.5\%), sedangkan Reseptor Progresteron (PR) positif ada 26 pasien (35.6\%).Human epidermal growth faktor receptor-2 (HER-2/neu) positif ada 15 pasien (20.59\%).Grading Histopatologi kanker payudara dalam penelitian ini mayoritas grade 3 yaitu ada 47 pasien (64.4\%).

Tabel 1. Hubungan Reseptor Estrogen(ER) dengan Grading Hipatologi Kanker Payudara

\begin{tabular}{|c|c|c|c|c|c|}
\hline \multirow{2}{*}{ ER } & \multicolumn{3}{|c|}{ Grade } & \multirow{2}{*}{ Total } & \multirow{2}{*}{$\mathrm{P}$} \\
\hline & 1 & 2 & 3 & & \\
\hline Negatif & 3 & 14 & 30 & 47 & \multirow{4}{*}{0,901} \\
\hline Positif & 1 & 8 & 17 & 26 & \\
\hline \multirow[b]{2}{*}{ Total } & 4 & 22 & 47 & 73 & \\
\hline & $\begin{array}{c}5.5 \\
\%\end{array}$ & $30.1 \%$ & $64.4 \%$ & $\begin{array}{c}100,0 \\
\%\end{array}$ & \\
\hline
\end{tabular}

Hubungan reseptor estrogen (ER) dengan grading hispatologi kanker payudara berdasarkan tabel 1 diketahui bahwa pasien dengan Reseptor Estrogen(ER) negatif terdapat47 pasien dan sebagian besar dengan kanker payudara grade 3 yaitu ada 30 pasien (63.8\%). Pasien dengan Reseptor
Estrogen(ER) positif terdapat 26 pasien dan sebagian besar dengan kanker payudara grade 3 yaitu ada 17 pasien $(65,4 \%)$.

Hasil uji penelitian pada tabel 1 didapatkan nilai $p=0,901 \quad(p>0,05)$,ini menunjukkan tidak terdapat hubungan yang signifikan antara Reseptor Estrogen(ER) dengan grading histopatologi kanker payudara.

4. Hubungan Reseptor Progresteron (PR) Dengan Grading Hipatologi Kanker Payudara

Tabel 2. Hubungan Reseptor Progresteron (PR) dengan Grading Hipatologi Kanker Payudara

\begin{tabular}{|c|c|c|c|c|c|}
\hline \multirow{2}{*}{ PR } & \multicolumn{3}{|c|}{ Grade } & \multirow[t]{2}{*}{ Total } & \multirow{2}{*}{ PR } \\
\hline & 1 & 2 & 3 & & \\
\hline Negatif & 3 & 16 & Negatif & 3 & \multirow{5}{*}{0.512} \\
\hline Positif & 1 & 6 & Positif & 1 & \\
\hline \multirow{3}{*}{ Total } & 4 & 22 & Total & 4 & \\
\hline & 5.5 & 30.1 & & $5.5 \%$ & \\
\hline & $\%$ & $\%$ & & & \\
\hline
\end{tabular}

Berdasarkan tabel 2 diketahui bahwa pasien dengan Reseptor Progresteron (PR) negatif ada 47 pasien dan sebagian besar dengan kanker payudara grade 3 yaitu ada 28 pasien (59.6\%). Pasien dengan Reseptor Reseptor Progresteron (PR) positif ada 26 pasien dan sebagian besar dengan kanker payudara grade 3 yaitu ada 19 pasien $(73.1 \%)$

Hasil uji penelitianmelalui tabel 2 didapatkan nilai $\mathrm{p}=0,512(\mathrm{p}>0,05)$,ini menunjukkan tidak terdapat hubungan yang signifikan antara Reseptor Prgresteron (PR) dengan grading histopatologi kanker payudara.

Berdasarkan tabel 3 diketahui bahwa pasien dengan Human epidermal growth faktor receptor-2 (HER-2/neu) negatif ada 58 pasien dan sebagian besar dengan kanker payudara grade 3 yaitu ada 36 pasien (62.1\%). Pasien dengan Human epidermal growth faktor receptor-2 (HER-2/neu) positif ada 15 
Warjianto et al. Hubungan Reseptor Estrogen, Reseptor Progesteron dan Ekspresi Her-2/Neu dengan Grading Histopatologi pada Pasien Kanker Payudara di RSUD dr. Moewardi Surakarta

pasien dan sebagian besar dengan kanker payudara grade 3 yaitu ada 11 pasien $(73.3 \%)$

Tabel 3. Hubungan Human epidermal growth faktor receptor-2 (HER-2/neu) dengan Grading Hipatologi Kanker Payudara

\begin{tabular}{|c|c|c|c|c|c|}
\hline \multirow{2}{*}{$\begin{array}{l}\text { HER- } \\
2 / \text { neu }\end{array}$} & \multicolumn{3}{|c|}{ Grade } & \multirow{2}{*}{ Total } & \multirow{2}{*}{$\mathrm{P}$} \\
\hline & 1 & 2 & 3 & & \\
\hline Negatif & 3 & 19 & 36 & 58 & \\
\hline Positif & 1 & 3 & 11 & 15 & \\
\hline & 4 & 22 & 47 & 73 & 0.629 \\
\hline Total & $5.5 \%$ & $30.1 \%$ & $\begin{array}{c}64.4 \\
\%\end{array}$ & $\begin{array}{c}100.0 \\
\%\end{array}$ & \\
\hline
\end{tabular}

Hasil uji Chi Square melalui tabel 3 didapatkan nilai $\mathrm{p}=0,629(\mathrm{p}>0,05)$, ini menunjukkan tidak terdapat hubungan yang signifikan antara Human epidermal growth faktor receptor-2 (HER-2/neu) dengan grading histopatologi kanker payudara.

\section{PEMBAHASAN}

Hasil uji Chi Square melalui tabel 1 didapatkan nilai $\mathrm{p}=0,901(\mathrm{p}>0,05)$ yang berarti bahwa tidak terdapat hubungan yang signifikan antara Reseptor Estrogen (ER) dengan grading histopatologi kanker payudara.

Pada wanita post menopause memiliki kadar ER lebih tinggi dibandingkan dengan wanita premenopause, dimana kanker payudara dengan ER- dan / atau PRmempunyai resiko mortalitas lebih tinggi daripada ER+ dan / atau PR+. Penelitian lain menunjukkan bahwa sekitar 50-60\% dari wanita dengan tumor ER-positif berespon baik pada terapi hormon dan kemoterapi dibandingkan dengan sekitar $8 \%$ dari wanita dengan tumor ER-negatif, dan relatif memiliki prognosis yang lebih buruk ${ }^{4}$.

Kejadian karsinoma payudara pada wanita yang berumur $<50$ tahun memiliki ER positif yang tinggi bahkan bisa mencapai duapertiga, sedangkan pada wanita berusia $>50$ tahun sekitar $80 \%$ tumor adalah ER positif, sehingga akan berpengaruh yang signifikan dalam teraupetik ${ }^{8}$

Dari hasil studi epidemiologis secara konsisten menunjukkan peningkatan 2-3 kali lipat dalam risiko kanker payudara pada wanita dengan peningkatan kadar estradiol darah. Di sisi lain, hasil yang tidak konsisten pada peran metabolit estrogen ${ }^{2}$.

Pada wanita premenopause masih sedikit dilakukan penelitian terhadap efek estrogen endogen pada risiko kanker payudara dibandingkan dengan wanita pascamenopause. Dengan demikian, peran estrogen dalam karsinogenesis payudara pada populasi ini tidak sepenuhnya dipahami dan tetap relatif tidak jelas. Kecilnya dari kasus kanker payudara pada wanita premenopause dan variasi inter- dan intra-individu yang besar dalam konsentrasi hormon seks selama siklus menstruasi² ${ }^{2}$.

Peran estrogen endogen sebagai karsinogen pada wanita premenopause tidak setinggi pada wanita pasca menopause sehingga belum didapatkan kesimpulan yang pasti ${ }^{2}$.

Secara keseluruhan, hasil dari penelitian terhadap peran metabolit estrogen sebagai karsinogen tidak konsisten, mungkin karena kecilnya ukuran penelitian dan penetrasi mutasi yang rendah dalam gen di jalur multigenik ${ }^{2,8}$.

Pada penelitian yang pernah dilakukan oleh Aryandono et al dari 238 pasien dengan kanker payudara didapatkan ER positif pada 124 pasien (52.1\%) lebih tinggi dibanding ER negatif pada 114 pasien (47.9\%). Dari hasil uji Chi Square didapatkan nilai $\mathrm{p}=0,334 \quad(\mathrm{p}>0,05)$ yang berarti bahwa tidak terdapat hubungan yang signifikan antara Reseptor Estrogen(ER) dengan grading histopatologi kanker payudara. ${ }^{5}$

Hasil ini didukung penelitian lain bahwa tingginya kadar estradiol dalam plasma 
darah tidak berhubungan dengan tingginya grading histopatologi kanker payudara, tetapi yang berpengaruh terhadap grading histopatologi kanker payudara adalah lamanya paparan terhadap estradiol ${ }^{7}$.

Hasil penelitian lain, bahwa dari 195 pasien terdapat pasien dengan ER negatif sebanyak 132 pasien (68\%) dibanding dengan PR positif sebanyak 63 pasien (32\%). Dari hasil uji Chi Square didapatkan nilai $\mathrm{p}=0,089$ $(p>0,05)$ yang berarti bahwa tidak terdapat hubungan yang signifikan antara Reseptor Estrogen(ER) dengan grading histopatologi kanker payudara ${ }^{6}$.

Hasil penelitian ini juga menunjukan bahwa pasien dengan Reseptor Estrogen(ER) negatif ada 50 pasien dan sebagian besar dengan kanker payudara grade 3 yaitu ada 35 pasien $(70,0 \%)$. Pasien dengan Reseptor Estrogen(ER) positif ada 23 pasien dan sebagian besar dengan kanker payudara grade 3 yaitu ada 15 pasien $(65,2 \%)$.

Pada hasil penelitian ini terdapat kecenderungan dengan ER negatif lebih tinggi yaitu 47 pasien dibanding dengan ER positif yaitu 26 pasien. Begitu juga pasien dengan high grade (grade 3) sebanyak 47 pasien (64.4\%) cenderung lebih tingi dibanding dengan low grade (grade 1) sebanyak 4 pasien $(5.5 \%)$. Data ini sesuai dengan hasil penelitian lain yang menyatakan bahwa pada populasi Asia cenderung mempunyai high grade (grade 3) lebih tingi dibanding dengan low grade $(\text { grade } 1)^{5,6}$.

Diketahui bahwa tidak terdapat hubungan yang signifikan antara Reseptor Prgresteron (PR) dengan grading histopatologi kanker payudara $(\mathrm{p}=0,512)$. Progesterone Receptors $(P R)$ merupakan gen yang diregulasi oleh estrogen, sehingga adanya ekspresi PR sebagai tanda adanya jalur ER yang sedang aktif serta bermanfaat dalam memprediksi perilaku karsinoma payudara ${ }^{9}$.

Proses metabolisme progresteron dalam jaringan menghasilkan metabolit progesteron pada sel yang akan mempengaruhi proliferasi, mitosis, dan apoptosis.

Tingginya ekspresi PR berimplikasi terhadap respons terapi hormonal tamoxifen yang lebih bagus pada penderita kanker payudara sebagai terapi adjuvant dan juga pada penderita yang mengalami metastase.

Pada penelitian yang pernah dilakukan oleh Aryandono et al., 2006, didapatkan PR negatif pada 117 pasien (51.5\%) lebih tinggi dibanding ER positif pada 110 pasien $(48.5 \%)^{5}$. Hal ini juga didukung dari hasil penelitian lain, bahwa dari 195 pasien terdapat pasien dengan PR negatif sebanyak 135 pasien (70.32\%) dibanding dengan PR positif sebanyak 57 pasien (29.68\%). Dari hasil uji Chi Square didapatkan nilai $\mathrm{p}=0,117 \quad(\mathrm{p}>0,05) \quad$ yang berarti bahwa tidak terdapat hubungan yang signifikan antara Reseptor Progesteron(PR) dengan grading histopatologi kanker payudara 6 .

Pada hasil penelitian ini terdapat kecenderungan dengan PR negatif lebih tinggi yaitu 47 pasien dibanding dengan PR positif yaitu 26 pasien. Begitu juga pasien dengan high grade (grade 3) sebanyak 47 pasien (64.4\%) cenderung lebih tingi dibanding dengan low grade (grade 1) sebanyak 4 pasien $(5.5 \%)$. Data ini sesuai dengan hasil penelitian lain yang menyatakan bahwa pada populasi Asia cenderung mempunyai high grade (grade 3) lebih tingi dibanding dengan low grade (grade 1) ${ }^{5,6}$.

Reseptor estrogen(ER) tidak memiliki hubungan yang signifikan dengan grading kanker payudara karena hasil dari penelitian terhadap peran metabolit estrogen sebagai karsinogen tidak konsisten, mungkin karena kecilnya ukuran penelitian dan penetrasi mutasi yang rendah dalam gen di jalur multigenik maka tentunya memiliki pengaruh terhadap hubungan Progesterone Receptors 
(PR) dengan grading histopatologi kanker payudara.

Her-2 adalah anggota family erbB/Her dari reseptor transmembran tirosin kinase terletak pada kromosom $17 \mathrm{q} 21$ yang dikode oleh gen Her-2 yang mempunyai fungsi dalam pertumbuhan sel, proliferasi dan pembelahan sel normal. Overekspresi dan amplifikasi gen $E r b B 2$ tampak pada beberapa jenis karsinoma, terutama karsinoma payudara 10.

Hasil penelitian menunjukan bahwa tidak terdapat hubungan yang signifikan antara Human epidermal growth faktor receptor-2 (HER-2/neu) dengan grading kanker payudara $(\mathrm{r}=0,112 ; \mathrm{p}=0,629)$.

Her-2 onkogen sangat berkaitan dengan sifat keagresifan tumor meningkatnya amplifikasi dan juga berperan dalam tumorigenesis dan metastasis. Apabila terjadi overekspresi Her-2 dan amplifikasi gen Her-2 mempengaruhi prognostik pada karsinoma payudara dan dapat digunakan sebagai petanda target terapi, sehingga pemeriksaan imunohistokimia Her-2/neu menjadi suatu prosedur standar pada kasus karsinoma payudara duktal invasif ${ }^{10}$.

Reseptor HER sebagai monomer yang terdapat pada permukaan sel. Setelah ligan mengikat domain ekstraselulernya, protein HER mengalami dimerisasi dan transfosforilasi domain intraselulernya. HER2 tidak memiliki ligan pengaktivasi langsung yang diketahui dan dapat dalam keadaan aktif secara konstitutif atau menjadi aktif setelah heterodimerisasi dengan anggota keluarga lainnya seperti HER1 dan HER3.

Reseptor HER tidak berpengaruh signifikan terhadap grading kanker, karena dimerisasi HER2 mempromosikan mislocalization dan degradasi cepat protein penghambat siklus sel p27Kip1 yang mengarah ke perkembangan siklus sel. HER2 juga dapat diaktifkan dengan pengompleksan dengan reseptor membran lain seperti reseptor faktor pertumbuhan seperti insulin

Hasil penelitian menunjukan bahwa tidak terdapat hubungan yang signifikan antara Human epidermal growth faktor receptor-2 (HER-2/neu) dengan grading hisyopatologi kanker payudara $(\mathrm{p}=0,389)$.

Hal ini juga didukung dari hasil penelitian lain, bahwa dari 54 pasien terdapat pasien dengan her-2 negatif sebanyak 33 pasien (61.1\%) dibanding dengan Her-2 positif sebanyak 21 pasien (38.9\%). Dari hasil uji Chi Squaredidapatkan nilai $\mathrm{p}=0,53$ $(p>0,05)$ yang berarti bahwa tidak terdapat hubungan yang signifikan antara Ekspresi Her-2/neu dengan grading histopatologi kanker payudara ${ }^{11}$.

Hasil tersebut bisa disebabkan oleh adanya mutasi yang lain selain dari gen HER2 (protoonkogen) yang merupakan penyebab terjadinya kanker payudara. Sebagaimana diketahui bahwa terdapat empat kelompok gen pengatur regulasi normal, yaitu gen yang merangsang pertumbuhan protoonkogen, penghambatan tumor supresor gen, regulasi terhadap apoptosis (programmed cell death) dan gen yang melibatkan DNA repair. Bila terjadi ganguan pada salah satu gen tersebut dapat menyebabkan kanker payudara. Hal ini tidak sejalan dengan Chabner \& Longo (2011) yang mengatakan bahwa pasien kanker payudara dengan over ekespresi HER2+ berhubungan dengan differensiasi buruk, keganasan tumor yang lebih tinggi, resistensi terhadap terapi, kekambuhan yang tinggi, insiden yang lebih tinggi dari metastasis otak, prognosis buruk, presentase sel yang berproliferasi lebih tinggi, aneuploid DNA, dan reseptor hormonal yang lebih sedikit (reseptor estrogen dan reseptor progesteron) 11 .

\section{SIMPULAN}

1. Tidak terdapat hubungan antara Reseptor Estrogen dengan grading 
Warjianto et al. Hubungan Reseptor Estrogen, Reseptor Progesteron dan Ekspresi Her-2/Neu dengan Grading Histopatologi pada Pasien Kanker Payudara di RSUD dr. Moewardi Surakarta

Histopatologi pada pasien kanker payudara di RSUD dr. Moewardi Surakarta Jawa Tengah $(\mathrm{p}=0,901)$.

2. Tidak terdapat hubungan antara Reseptor Progesteron dengan grading Histopatologi pada pasien kanker payudara di RSUD dr. Moewardi Surakarta Jawa Tengah ( $p=0,512)$.

3. Tidak terdapat hubungan antara Ekspresi Her-2/neu dengan grading Histopatologi pada pasien kanker payudara di RSUD dr. Moewardi Surakarta Jawa Tengah $(\mathrm{p}=0,629)$.

\section{DAFTAR PUSTAKA}

1. Kementerian Kesehatan RI (2015). Buletin Kanker. Pusat Data dan Informasi Kementrian Kesehatan RI 2015, pp. 1-35.

2. Samavat H, Kurzer MS (2015). Estrogen metabolism and breast cancer, Cancer Letters. Elsevier Ireland Ltd, 356(2), pp. 231-243.

3. Ambroise M, Ghosh M, Mallikarjuna VS, Kurian A (2011). Immunohistochemical Profile of Breast Cancer Patients at a Tertiary Care Hospital in South India.Asian Pacific J Cancer Prev, 12, pp. 625-629.

4. Bhurgri $\mathrm{Y}$, Nisa A, Raza F, Kayani N (2008).Comparison of ER, PR \& HER2/neu (C-erb B 2) Reactivity Pattern with Histologic Grade, Tumor Size and Lymph NodeStatus in Breast Cancer. Pakistan. Asian Pacific J Cancer Prev, 9, 553-556.

5. Aryandono T, Harijadi, Soeripto (2006). Hormone reseptor status of operable breast cancer in Indonesia: Correlation with other prognostic faktors and survival. Asian Pacific Journal of Cancer Prevention. Vol 73. p321-324.

6. Kamil M, Khalid, Khalid I, Hashim H, Biswas M, KaurG and Islam R (2010). Association of Carcinoma Breast: Grade and Estrogen. Journal of the College of Physicians and Surgeons Pakistan. Vol. 20 (4): 250-252
7. Soewoto W, Mudigdo A, Aryandono T, Dirgahayu P (2018). The Association Between Estradiol Level, Remission, and Survival in Breast Cancer Patients at Dr. Moewardi Hospital Surakarta Central Java. In : Mid International Conference On Public Health 2018; April 18 - 19, 2018.

8. Yager JD, Davidson NE (2006). Mechanisms of Disease, Estrogen Carsinogenesis in Breast Cancer. New England J Med; 354(3):270-79.

9. Ellis IO, Schinitt SJ, Sastre GX (2003). Invasive Breast Carcinoma in World Health Organization Classification of Tumours Pathology \& Genetics Tumours of the Breast and Female Genital Organs. IARC, p13-59.

10. Hutagulung SB, Mulyadi IK, Artha IGA (Mei 2014).Ekspresi Ki-67 dan HER2/neu Berhubungan dengan Derajat Histopatologik Karsinoma Payudara Invasif No Special Type (NST). Departemen Patologi Anatomik, Fakultas Kedokteran, Universitas UdayanaDenpasar-Bali.Vol 23 No. 2.Awolaran OT(2015). Cellular Mechanisms of Oestrogen in Breast Cancer Development.The Open Access Journal of Science and Technology Vol. 3.

11. Muhartono, ramanisa $\mathrm{S}$, Mutiara $\mathrm{H}$, Riduan RJ (2016).Hubungan antara status reseptor estrogen, reseptor progesteron dan human epidermal growth faktor receptor 2 dengan derajat keganasan karsinoma payudara invasif.Majalah Kedokteran Andalas, Vol.39, No.2, Agustus 2016, hal. 65-72.

12. Badan Penelitian dan Pengembangan Kesehatan (2013).Riset Kesehatan Dasar (RISKESDAS) 2013, Laporan Nasional 2013. Jakarta.

13. Duffy MJ (2006). ESTROGEN RECEPTORS: Role in Breast Cancer. Critical Reviews in Clinical Laboratory Sciences, 43(4):325-347

14. Geethamala K, Murthy S, Vani BR, Rao S (2015). Histopathological Grade Versus Hormone Receptor Status in Breast 
Warjianto et al. Hubungan Reseptor Estrogen, Reseptor Progesteron dan Ekspresi Her-2/Neu dengan Grading Histopatologi pada Pasien Kanker Payudara di RSUD dr. Moewardi Surakarta

Carcinoma - Treasure The Past.International Journal of Biomedical Research, 6(7), pp. 466-471.

15. Ghoncheh M, Mirzaei M, Salehiniya H (2016). Incidence and Mortality of Breast Cancer and their Relationship with the Human Development Index ( HDI ) in the World in 2012.Asian Pac J Cancer Prev, 17, Cancer Control in Western Asia Special Issue, 43-46.

16. Guyton A, Hall J (2008).Buku Ajar Fisiologi Kedokteranedisi 11. Jakarta: EGC.

17. Iqbal N, Iqbal N 2014. Human Epidermal Growth Faktor Receptor 2 (HER2) in Cancers: Overexpression and Therapeutic Implications. Hindawi Publishing Corporation.

18. Lange CA, Yee D (2008). Progesterone and breast cancer. Womens Health (Lond Engl). March ; 4(2): 151-162.

19. Rakha EA, Filho JSR, Baehner F, Dabbs D, Decjer T, Eusebi V, Fox SB, Ichihara S, Jacquemier J, Lakhani SR, Palacios J, Richardson AL, Schnitt SJ, Schmit FC, Tan PH, Tse GM, Budve S, Ellis IO (2010). Breast cancer prognostic classification in the molecular era: the role of histological grade. Nottingham. http://breast-cancerresearch.com/content/12/4/207

20. Utomo ARH (2017). Memahami Proses Karsinogenesis Kanker Payudara. Manajemen Terkini Kanker Payudara. Jakarta, media Aeskulapius.

21. Wiebe JP (2006). Progesterone metabolites in breast cancer. EndocrineRelated Cancer, 13(3), pp. 717-738. 